\title{
Determining Digital Literacy Competencies in Technical Senior High Schools Using Fuzzy Delphi Analysis
}

\author{
David W. S. Tai, Ren-Cheng Zhang, Yu-Te Wang, and Ray Wang
}

\begin{abstract}
The main purpose of this study was to establish appropriate competency indicators for Digital literacy of technical senior high schools in Taiwan. The paper describes and discusses the final results by using the expert panel and Fuzzy Delphi method, involving 32 experts from academia, school teacher and industrial information related areas. Furthermore, the Fuzzy Delphi technique was conducted and 53 competency indicators were proposed after this process. In the finding of the Fuzzy Delphi analysis, the experts thought that the most important competencies are "Recognize the legal consequences of plagiarism and the need for personal authenticity in their work", "Respects intellectual property rights", and "Recognize that using media or technology to defame, libel, or misrepresent another person or group constitutes unacceptable behavior".
\end{abstract}

Index Terms—Digital literacy, expert panel, fuzzy Delphi.

\section{INTRODUCTION}

Gilster [1] first used the term "digital literacy" in the context of a wider reflection on the potentials of the Internet and defined it as $\ulcorner$ the ability to understand and use information in multiple formats from a wide range of sources when it is presented via computers' (p. 1) $\lrcorner$. Digital literacy or as it is termed by some, digital literacies have received a great deal of attention in the recent years with much wrangling over definitions and the extent of this term [2]. Subsequently, a broader concept appeared, transcending technical ICT skills and including skills linked to the capacity to solve information and communication problems in a digital environment. For example, searching, assessing, summarizing, analyzing, representing, or creating information; as well as sharing and collaborating with others [3]. Leading professional organizations have called for increased integration of digital literacy into the school curriculum, including the ability to find and evaluate information on the Internet [4]. So far, little research has been focused on student performance in a digital context, partly due to the difficulty of defining and measuring ICT or digital skills [3]. Middle school is a logical focal point for increasing integration of digital literacy into the

Manuscript received April 20, 2016; revised June 22, 2016. This work was supported by the Ministry of Science and Technology, Taiwan, R.O.C. under Contract Nos. MOST 104-2511-S-241-008

David W. S. Tai is with the Dept. of Computer Science and Information Management, Hungkuang University, Taichung 43302, Taiwan (e-mail: david60123@gmail.com).

Ren-Cheng Zhang and Yu-Te Wang are with the Dept. of Industrial Education and Technology, National Changhua University of Education, Changhua 500, Taiwan (clayclctw@ hotmail.com, te@ms.tcgs.tc.edu.tw).

Ray Wang is with the Dept. of Hospitality Management, Hungkuang University, Taichung 43302, Taiwan (e-mail: ketr501215@sunrise.hk.edu.tw). curriculum [4]. Updating these abilities will be necessary, as people's circumstances change and as changes in the digital information environment bring about the need for new understandings and abilities [5]. Therefore, this study suggests that digital literacy competencies need for more in-depth discussion and research.

\section{LITERATURE REVIEW}

\section{A. Digital Literacy}

As central topics in the information sciences and $21 \mathrm{st}$ century education, information literacy and digital literacy have been discussed in research studies with varied terminologies and meanings [6]. Digital literacy is a broader concept than ICT literacy. In general, digital literacy frameworks may be reflected in the use of digital technology, communication tools and networks to access, manage, integrate, evaluate and create information in order to function in the information society [7]. It also includes elements of information literacy, media literacy, and visual literacy [8]. Digital literacy refers to the knowledge and skills that all persons need for professional development and for active participation in a technological-based society [9]. Digital literacy skills also including experiences with and management of e-safety and risk [10]. Digital literacy is a broader concept that integrates several skill-sets and related literacies, such as information evaluation and knowledge gathering [11]. Digital literacy also includes skills in critical information retrieval, data processing and the ability to take advantage of the diversity of digital media [12]. In recent years, studies of digital literacy accentuate the need of getting beyond the basic skills of using the information and digital literacy tools and resources and developing strategies for a critical and efficient use of these means [13].

JISC definition used in this study will be divided into following digital literacy: 1. Media literacy: Critically read and creatively produce academic and professional communications in a range of media; 2. Information literacy: Find, interpret evaluate, manage and share information; 3 . ICT literacy: Adopt, adapt and use digital devices, applications and services; 4 . Learning skills: Study and learn effectively in technology-rich environments, formal and informal; 5. Communications \& collaboration: Participate in digital networks for learning and research; 6. Career \& identity management: Manage digital reputation and online identity [14]. 


\section{A. Fuzzy Delphi}

Fuzzy Delphi Method (FDM) was derived to solve the problem of traditional Delphi method [15]. This method bases on group thinking of the qualified experts that assures the validity of the collected information [16]. The operational stages of the modified fuzzy Delphi method are as follows [17].

Stage 1: Collect the fuzzy interval values of relevance scores. This study collected the interval values of the relevance scores assigned by experts to each evaluation criterion. The minimum interval value (most conservative cognitive value) is indicated by $\mathrm{C}$, while the maximum value (most optimistic cognitive value) is indicated by $\mathrm{O}$; $\mathrm{a}$ is the optimal representative value as determined by experts (subjective cognitive value). $\mathrm{C}^{\mathrm{i}}, \mathrm{O}^{\mathrm{i}}$ and $\mathrm{a}^{\mathrm{i}}$ respectively represent the minimum value, maximum value, and subjective cognitive value of the relevance score for evaluation criterion i.

Stage 2: Eliminate extreme values. This study calculated the mean and standard deviation of the minimum value, maximum value, and subjective cognitive value of evaluation criterion i. Extreme values that fell beyond the range of mean \pm 2 standard deviation were eliminated.

Stage 3: Determine the triangular fuzzy number for the relevance scores of assessment factors.

Stage 4: Test for consistency. The gray zone test was used to test for consistency among the opinions of experts (test value $\left.\mathrm{Z}^{\mathrm{i}}=\left(\mathrm{O}_{\mathrm{M}}^{\mathrm{i}}-\mathrm{C}_{\mathrm{M}}^{\mathrm{i}}\right)-\left(\mathrm{C}_{\mathrm{U}}^{\mathrm{i}}-\mathrm{O}_{\mathrm{L}}^{\mathrm{i}}\right)\right)$. When $\mathrm{C}_{\mathrm{U}}^{\mathrm{i}}>\mathrm{O}_{\mathrm{L}}^{\mathrm{i}}$ and $\mathrm{Z}$ $\geqq 0$, this indicates expert opinions are converging (consistent).

Stage 5: Calculate the value of consensus among experts. In Figure 1, the cognitive value corresponding to the intersection point of $\mathrm{C}^{\mathrm{i}}$ and $\mathrm{O}^{\mathrm{i}}$ is the value of consensus among experts (indicated by $G^{i}$ ) in relation to the relevance score of evaluation criterion $i$. The higher the value of $G$ is, the higher the consensus among experts of the significance of this assessment factor.

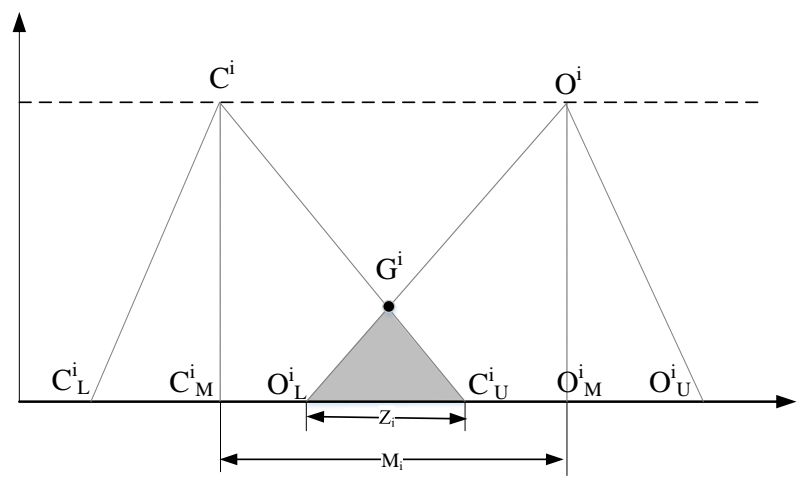

Fig. 1. Two triangular fuzzy numbers.

\section{B. Participants}

The study used the expert panel, Fuzzy Delphi method approach to conduct the basis competencies of Digital literacy, and the main goal of using the Fuzzy Delphi method was to collect and conclude the opinions from 32 industrial, school teacher and the academic experts in the information related areas. The first phase of data collection involved semi-structured interview with 32 experts in digital literacy based in the different field. The digital literacy identified form the researcher were used for develop the "Digital literacy Fuzzy Delphi Survey".

Second phase, the "Digital literacy Fuzzy Delphi Survey" is to get the agreement based on the themes given by the experts. The consensus survey will be using the Fuzzy linguistic scale anchored in strongly disagree and strongly agree. Experts will be required to indicate the extent of their agreement with the statements given. It will be constructed based on the experts raised from the conducted interview in the previous phase. For this purpose about 32 experts in Digital literacy involved and responses the survey.

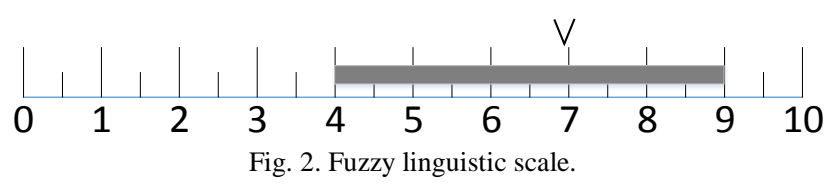

Fuzzy Delphi technique were conducted and 53 competency indicators were proposed after this process. In addition, it should be at least five to ten per category from different professional groupings [14]. Overall, there were 32 participants in the whole process, and the effective response rate was $100 \%$, and there were 9 participants from the academia, 15 participants from the school and 8 from the industry as shown in Table I. Therefore, it fitted in with the assumption.

TABLE I: DELPHI GROUPINGS AND NUMBER OF PARTICIPANTS

\begin{tabular}{ccc}
\hline Type & No. & Percentage \\
\hline Academia & 9 & $28 \%$ \\
School teacher & 15 & $47 \%$ \\
Industry & 8 & $25 \%$ \\
\hline Sum & 32 & $100 \%$ \\
\hline \hline
\end{tabular}

\section{RESULTS}

Based on the literature review and expert panel, the dimension of digital literacy are Media literacy, Information literacy, ICT literacy, learning skills, communications \& collaboration, and career \& identity management. According to the survey of the Fuzzy Delphi, the total number of competency indicators is 53. The number of each individual dimension is shown in Table II. Overall the indicator $G^{i}$ are over mean 7.088, and it means the experts agreed the indicators are fairly important (see Table III-VIII).

TABLE II: NUMBER OF DIMENSIONS AND INDICATORS

\begin{tabular}{cc}
\hline \hline Dimensions & Number of indicators \\
\hline Media literacy & 4 \\
Information literacy & 10 \\
ICT literacy & 4 \\
Learning skills & 7 \\
Communications \& collaboration & 6 \\
Career \& identity management & 22 \\
\hline Sum & 53 \\
\hline \hline
\end{tabular}

TABLE III: RESULTS OF FUZZY DELPHI IN MEDIA LITERACY

\begin{tabular}{clccccc}
\hline \hline $\begin{array}{c}\text { Serial } \\
\text { no }\end{array}$ & \multicolumn{1}{c}{ Indicator } & $C_{U}^{i}$ & $O_{L}^{i}$ & $Z^{i}$ & $M^{i}$ & $G^{i}$ \\
\hline & $\begin{array}{l}\text { Identify common graphic, video, } \\
\text { and sound file formats (e.g., JPEG, }\end{array}$ & 8 & 7 & 1 & 3.420 & 7.335 \\
T11 & $\begin{array}{l}\text { GIF, MPEG, QUICKTIME, and } \\
\text { WAV). }\end{array}$ & & & & & \\
&
\end{tabular}


T12

joy reading or listening for pleasure.

T13 Express personal reading or listening experience. Use draw, paint, graphics, or

$\begin{array}{lllllll}\text { T14 presentation software to visually } & 8.5 & 6.5 & 2 & 3.209 & 7.195\end{array}$ communicate ideas or concepts.

TABLE IV: RESULTS OF FUZZY DELPHI IN INFORMATION LITERACY

\begin{tabular}{|c|c|c|c|c|c|c|}
\hline $\begin{array}{c}\text { Serial } \\
\text { no }\end{array}$ & Indicator & $C^{i}{ }_{U}$ & $O_{L}^{i}$ & $Z^{i}$ & $M^{i}$ & $G^{i}$ \\
\hline $\mathrm{T} 21$ & $\begin{array}{l}\text { Use advanced search tools and } \\
\text { techniques or simulations and } \\
\text { digital models to locate or generate } \\
\text { precise data and information that } \\
\text { supports the development of new } \\
\text { understandings. }\end{array}$ & 8 & 7 & 1 & 3.406 & 7.160 \\
\hline $\mathrm{T} 22$ & $\begin{array}{l}\text { Select and use a range of ICT } \\
\text { independently and collaboratively, } \\
\text { analyses information to frame } \\
\text { questions and plan search } \\
\text { strategies or data generation. }\end{array}$ & 8 & 7 & 1 & 3.139 & 7.265 \\
\hline $\mathrm{T} 23$ & $\begin{array}{l}\text { Search, read, log, and note take } \\
\text { information from a variety of } \\
\text { sources (e.g., } \\
\text { encyclopedias, databases, eBooks } \\
\text { available on the school library } \\
\text { website, the Internet). }\end{array}$ & 8 & 8 & 0 & 3.255 & 7.604 \\
\hline $\mathrm{T} 24$ & $\begin{array}{l}\text { Independently develop keywords } \\
\text { and phrases to search for } \\
\text { information. }\end{array}$ & 8 & 3 & 0 & 3.357 & 7.751 \\
\hline $\mathrm{T} 25$ & $\begin{array}{l}\text { Use Boolean operators with } \\
\text { human or programmed guidance } \\
\text { to narrow or broaden searches. }\end{array}$ & 8 & 7 & 1 & 3.416 & 7.345 \\
\hline T26 & $\begin{array}{l}\text { Can review the information search } \\
\text { process, and revise the keyword if } \\
\text { necessary. }\end{array}$ & 8 & 5 & 3 & 3.524 & 7.188 \\
\hline $\mathrm{T} 27$ & $\begin{array}{l}\text { Manipulate graphics objects in a } \\
\text { word processing program }\end{array}$ & 8 & 7 & 1 & 3.238 & 7.408 \\
\hline $\mathrm{T} 28$ & $\begin{array}{l}\text { Organizes information for } \\
\text { practical application. }\end{array}$ & 8 & 7 & 1 & 2.799 & 7.252 \\
\hline T29 & $\begin{array}{l}\text { Can integrate information } \\
\text { technology to communicate } \\
\text { effectively express. }\end{array}$ & 8 & 7 & 1 & 3.306 & 7.208 \\
\hline $\mathrm{T} 210$ & $\begin{array}{l}\text { Identifies inaccurate } \\
\text { misleading information. }\end{array}$ & 8 & 5 & 3 & 3.138 & 7.228 \\
\hline
\end{tabular}

TABLE V: RESULTS OF FUZZY DELPHI IN ICT LITERACY

\begin{tabular}{|c|c|c|c|c|c|c|}
\hline $\begin{array}{c}\text { Serial } \\
\text { no }\end{array}$ & Indicator & $C_{U}^{i}$ & $O_{L}^{i}$ & $Z^{i}$ & $M^{i}$ & $G^{i}$ \\
\hline T31 & $\begin{array}{l}\text { Familiar with the use of ICT } \\
\text { systems and simple } \\
\text { troubleshooting. }\end{array}$ & 8 & 5 & 3 & 3.195 & 7.214 \\
\hline $\mathrm{T} 32$ & $\begin{array}{l}\text { Search for and access to Internet } \\
\text { resources and use its resources or } \\
\text { services. }\end{array}$ & 8 & 6 & 2 & 3.329 & 7.429 \\
\hline T33 & $\begin{array}{l}\text { Using ICT to address the daily life } \\
\text { and learning problems. }\end{array}$ & 8 & 7 & 1 & 3.4 & 7.387 \\
\hline T34 & $\begin{array}{l}\text { Manage and maintain data } \\
\text { securely in a variety of storage } \\
\text { mediums and formats. }\end{array}$ & 8 & 6 & 2 & 3.158 & 7.385 \\
\hline
\end{tabular}

TABLE VI: RESULTS OF FUZZY DELPHI IN LEARNING SKILLS

\begin{tabular}{|c|c|c|c|c|c|c|}
\hline $\begin{array}{c}\text { Serial } \\
\text { no }\end{array}$ & Indicator & $C_{U}^{i}$ & $O_{L}^{i}$ & $Z^{i}$ & $M^{i}$ & $G^{i}$ \\
\hline $\mathrm{T} 41$ & $\begin{array}{l}\text { Understanding Self-learning } \\
\text { ability how to influence lifelong } \\
\text { learning. }\end{array}$ & 8 & 7.5 & 0.5 & 3.617 & 7.317 \\
\hline $\mathrm{T} 42$ & $\begin{array}{l}\text { Establish personal goals in pursuit } \\
\text { of individual interests, academic } \\
\text { requirements, and career paths. }\end{array}$ & 7 & 7 & 0 & 3.289 & 7.165 \\
\hline $\mathrm{T} 43$ & $\begin{array}{l}\text { Work independently and take } \\
\text { responsibility for their study } \\
\text { progress. }\end{array}$ & 7 & 7 & 0 & 3.228 & 7.221 \\
\hline $\mathrm{T} 44$ & $\begin{array}{l}\text { Use eLearning to support and } \\
\text { extend learning }\end{array}$ & 8 & 7 & 1 & 2.999 & 7.273 \\
\hline $\mathrm{T} 45$ & Use digital tools for a curricular & 8.5 & 6 & 2.5 & 3.252 & 7.468 \\
\hline
\end{tabular}

purpose (e.g., digital camera,

voice recorder, interactive

technologies, digital

probes/sensors, hand-held devices,

GPS - Global Position Systems)

T46 Applies information in critical

thinking and problem solving.

Understand the importance of

T47 creativity, innovation, and invention.

TABLE VII: RESULTS OF FUZZY DELPHI IN COMMUNICATIONS \& COLLABORATION

\begin{tabular}{|c|c|c|c|c|c|c|}
\hline $\begin{array}{l}\text { Serial } \\
\text { no }\end{array}$ & Indicator & $C_{U}^{i}$ & $O_{L}^{i}$ & $Z^{i}$ & $M^{i}$ & $G^{i}$ \\
\hline T51 & $\begin{array}{l}\text { Shares knowledge and } \\
\text { information with others. }\end{array}$ & 8 & 8 & 0 & 3.286 & 7.416 \\
\hline T52 & $\begin{array}{l}\text { Involves not only communication } \\
\text { with technology, but also } \\
\text { consideration of audience. }\end{array}$ & 8 & 6 & 2 & 3.051 & 7.246 \\
\hline T53 & $\begin{array}{l}\text { Create, lead, participate, and } \\
\text { collaborate in an online } \\
\text { environment to support and extend } \\
\text { learning (e.g., email, online } \\
\text { forums, RSS feeds, virtual worlds, } \\
\text { video web conferences). }\end{array}$ & 8 & 5.5 & 2.5 & 3.169 & 7.197 \\
\hline T54 & $\begin{array}{l}\text { Respects others' ideas and } \\
\text { backgrounds and acknowledges } \\
\text { their contributions. }\end{array}$ & 8 & 8 & 0 & 3.252 & 7.770 \\
\hline & $\begin{array}{l}\text { Specify and detail workgroup } \\
\text { goals and individual and subgroup }\end{array}$ & & & & & \\
\hline T55 & $\begin{array}{l}\text { responsibilities finalize } \\
\text { workgroup strategies, resources, } \\
\text { budget, and timeline. }\end{array}$ & 8 & 6 & 2 & 3.185 & 7.237 \\
\hline T56 & $\begin{array}{l}\text { Can choose the appropriate } \\
\text { information technology in } \\
\text { cooperation with others for } \\
\text { complete the work. }\end{array}$ & 8 & 6 & 2 & 3.29 & 7.126 \\
\hline
\end{tabular}

TABLE VIII: RESULTS OF FUZZY DELPHI IN CAREER \& IDENTITY MANAGEMENT

\begin{tabular}{clccccc}
\hline \hline $\begin{array}{c}\text { Serial } \\
\text { no }\end{array}$ & \multicolumn{1}{c}{ Indicator } & $C^{i}{ }_{U} O_{L}^{i}$ & $Z^{i}$ & $M^{i}$ & $G^{i}$ \\
\hline T61 & $\begin{array}{l}\text { Exploration of Information } \\
\text { Technology with interest. }\end{array}$ & 8 & 6 & 2 & 3.216 & 7.271 \\
T62 & $\begin{array}{l}\text { Can be willing to explore } \\
\text { emerging information technology. }\end{array}$ & 8 & 7 & 1 & 3.329 & 7.118 \\
T63 & $\begin{array}{l}\text { Understand approach and career } \\
\text { development in IT-related } \\
\text { industry. }\end{array}$ & 7 & 7 & 0 & 2.903 & 7.358 \\
T64 & $\begin{array}{l}\text { Respects the principle of equitable } \\
\text { access to information. }\end{array}$ & 8 & 7 & 1 & 3.133 & 7.366 \\
T65 & $\begin{array}{l}\text { Respects intellectual property } \\
\text { rights. }\end{array}$ & 8 & 8 & 0 & 3.1 & 8.165 \\
\hline \hline
\end{tabular}

TABLE VIII: RESULTS OF FUZZY DELPHI IN CAREER \& IDENTITY MANAGEMENT CONTD

\begin{tabular}{clllllll}
\hline $\begin{array}{c}\text { Serial } \\
\text { no }\end{array}$ & Indicator & $\mathrm{C}_{\mathrm{U}}^{\mathrm{i}}$ & $\mathrm{O}_{\mathrm{L}}^{\mathrm{i}}$ & $\mathrm{Z}^{\mathrm{i}}$ & $\mathrm{M}^{\mathrm{i}}$ & $\mathrm{G}^{\mathrm{i}}$ \\
\hline $\mathrm{T} 66$ & $\begin{array}{l}\text { Able to cite all literature sources } \\
\text { correctly. } \\
\text { Explain why "fair use" is } \\
\text { T67 }\end{array}$ & 8 & 6.5 & 1.5 & 3.222 & 7.579 \\
& $\begin{array}{l}\text { permitted for educational purposes } \\
\text { but not in "for profit" situations. }\end{array}$ & 8 & 5 & 3 & 3.307 & 7.227 \\
$\mathrm{~T} 68$ & $\begin{array}{l}\text { Legally obtains, stores, and } \\
\text { disseminates text, data, images, or }\end{array}$ & 8 & 6 & 2 & 3.01 & 7.877 \\
T6unds. & $\begin{array}{l}\text { Distinguish among freeware, } \\
\text { shareware, and commercial } \\
\text { software. } \\
\text { Tecognize the legal consequences } \\
\text { of plagiarism and the need for } \\
\text { personal authenticity in their }\end{array}$ & 8 & 8 & 0 & 2.88 & 7.920 \\
T611 & $\begin{array}{l}\text { work. } \\
\text { Demonstrate an understanding of }\end{array}$ & 8 & 5.5 & 2.5 & 3.085 & 7.270 \\
\hline \hline
\end{tabular}




\begin{tabular}{|c|c|c|c|c|c|c|}
\hline & $\begin{array}{l}\text { the process for } \\
\text { copyrighting/protecting their own } \\
\text { original work. }\end{array}$ & & & & & \\
\hline T612 & $\begin{array}{l}\text { Understand the responsibility for } \\
\text { use of Information Technology. }\end{array}$ & 8.5 & 6.5 & 2 & 2.927 & 7.537 \\
\hline T613 & $\begin{array}{l}\text { Recognize the need for privacy of } \\
\text { certain data files or documents }\end{array}$ & 8 & 7.5 & 0.5 & 3.044 & 7.634 \\
\hline T614 & $\begin{array}{l}\text { Understand the IT-related legal, } \\
\text { ethical and social issues, to protect } \\
\text { themselves and respect others. }\end{array}$ & 8 & 7 & 1 & 2.709 & 7.591 \\
\hline T615 & $\begin{array}{l}\text { Recognize that using media or } \\
\text { technology to defame, libel, or } \\
\text { misrepresent another person or } \\
\text { group constitutes unacceptable } \\
\text { behavior. }\end{array}$ & 9 & 7 & 2 & 2.828 & 8.011 \\
\hline T616 & $\begin{array}{l}\text { Use technology efficiently and in a } \\
\text { manner that does not harm them or } \\
\text { others. }\end{array}$ & 9 & 7 & 2 & 2.847 & 7.799 \\
\hline T617 & $\begin{array}{l}\text { Able to adopt healthy usage and } \\
\text { attitude when using ICT. }\end{array}$ & 8.5 & 6.5 & 2 & 2.94 & 7.697 \\
\hline T618 & $\begin{array}{l}\text { Able to practice healthy lifestyle of } \\
\text { citizen in digital society. }\end{array}$ & 8 & 7 & 1 & 2.775 & 7.568 \\
\hline T619 & $\begin{array}{l}\text { Understand and demonstrate safe, } \\
\text { respectful, and responsible online } \\
\text { communication (e.g., email, } \\
\text { online forums, social networks, } \\
\text { ecommerce). }\end{array}$ & 9 & 8 & 1 & 3.071 & 7.894 \\
\hline Т620 & $\begin{array}{l}\text { Independently apply appropriate } \\
\text { strategies to protect rights, } \\
\text { identity, privacy and emotional } \\
\text { safety of others when using ICT. }\end{array}$ & 8 & 8 & 3 & 3.106 & 7.122 \\
\hline & $\begin{array}{l}\text { Use a range of strategies for } \\
\text { securing and protecting } \\
\text { information, assess the risks }\end{array}$ & & & & & \\
\hline T621 & $\begin{array}{l}\text { associated with online } \\
\text { environments and establish } \\
\text { appropriate security strategies and } \\
\text { codes of conduct. }\end{array}$ & 8 & 6 & 2 & 3.025 & 7.348 \\
\hline Т622 & $\begin{array}{l}\text { Manage and maintain data } \\
\text { securely in a variety of storage } \\
\text { mediums and formats. }\end{array}$ & 8 & 6 & 2 & 3.066 & 7.372 \\
\hline
\end{tabular}

\section{CONCLUSION}

This study used the expert panel and the Fuzzy Delphi method to clarify the viewpoints of Digital literacy competencies from the academia, school teacher and the industry experts. In the finding of the Fuzzy Delphi analysis, the experts thought that the most important competencies are "Recognize the legal consequences of plagiarism and the need for personal authenticity in their work", "Respects intellectual property rights", and "Recognize that using media or technology to defame, libel, or misrepresent another person or group constitutes unacceptable behaviour", from Career \& Identity Management. Next, "Distinguish among freeware, shareware, and commercial software", "Understand and demonstrate safe, respectful, and responsible online communication (e.g., email, online forums, social networks, ecommerce)" and "Legally obtains, stores, and disseminates text, data, images, or sounds" are important as well.

\section{ACKNOWLEDGMENT}

The authors would like to thank the Ministry of Science and Technology, R.O.C., for financially supporting this research under Contract No. <MOST 104-2511-S-241-008>.

\section{REFERENCES}

[1] P. Gilster, Digital Literacy, Wiley Computer Pub., 1997.
[2] E. Tan, "Informal learning on YouTube: exploring digital literacy in independent online learning," Learning Media and Technology, vol. 38, pp. 463-477, Dec. 1, 2013.

[3] M. Claro, T. Cabello, E. San Martin, and M. Nussbaum, "Comparing marginal effects of Chilean students' economic, social and cultural status on digital versus reading and mathematics performance," Computers \& Education, vol. 82, pp. 1-10, Mar. 2015.

[4] J. Colwell, S. Hunt-Barron, and D. Reinking, "Obstacles to developing digital literacy on the internet in middle school science instruction," Journal of Literacy Research, vol. 45, pp. 295-324, Sep. 2013.

[5] L. L. Martins and F. W. Kellermanns, "A model of business school students' acceptance of a web-based course management system," Academy of Management Learning \& Education, vol. 3, pp. 7-26, Mar. 2004.

[6] W. W. F. Lau and A. H. K. Yuen, "Developing and validating of a perceived ICT literacy scale for junior secondary school students: Pedagogical and educational contributions," Computers \& Education, vol. 78, pp. 1-9, Sep. 2014

[7] S. Javorsky and R. Horvath, "Phenomenon of digital literacy in scope of European cross-curricular comparison," in Proc. 3rd Cyprus International Conference on Educational Research (Cy-Icer 2014), vol. 143, pp. 769-777, 2014.

[8] A. Martin, "DigEuLit - A European framework for digital literacy: A progress report," Journal of eLiteracy, vol. 2, pp. 130-136, 2005.

[9] H. Uzunboylu, "A review of two mainline E-learning projects in the European Union," Etr\&D-Educational Technology Research and Development, vol. 54, pp. 201-209, Apr 2006.

[10] S. Cranmer, "Listening to excluded young people's experiences of e-safety and risk," Learning Media and Technology, vol. 38, pp. 72-85, Mar 12013

[11] S. Mohammadyari and H. Singh, "Understanding the effect of e-learning on individual performance: The role of digital literacy," Computers \& Education, vol. 82, pp. 11-25, Mar 2015.

[12] M. Thorell, P. K. Fridorff-Jens, P. Lassen, T. Lange, and L. Kayser, "Transforming students into digital academics: A challenge at both the individual and the institutional level," BMC Med Educ, vol. 15, p. 48, Mar 142015.

[13] T. Shopova, Integration of ICTS in Education and Raising the Digital Literacy of Students in the University Environment, 2014.

[14] JISC. (2015). Digital Literacy Framework. [Online]. Available: https://www.jisc.ac.uk/guides/developing-digital-literacies

[15] A. Ishikawa, M. Amagasa, T. Shiga, G. Tomizawa, R. Tatsuta, and H. Mieno, "The max-min Delphi method and fuzzy Delphi method via fuzzy integration," Fuzzy Sets and Systems, vol. 55, pp. 241-253, May 101993

[16] S. N. A. Mohamad, M. A. Embi, and N. Nordin, "Determining e-portfolio elements in learning process using fuzzy Delphi analysis," International Education Studies, vol. 8, p. 171, 2015.

[17] J.-H. Lin and C.-J. Yang, "Applying analytic network process to the selection of construction projects," Open Journal of Social Sciences, vol. 4 , p. 41, 2016

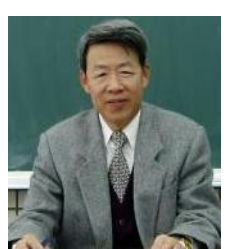

David Wen-Shung Tai is Professor of the Dept. of Computer Science and Information Management, Hungkuang University, Taichung, Taiwan. He earned his MS degree from the Dept. of Industrial Technology at the Univ. of Wisconsin-Platteville in the USA. He also earned his MS degree from the Dept. of Computer Science at Iowa State University in the USA, and his $\mathrm{PhD}$ from the Department of Industrial Education and Technology at the same University in 1987. Prof. Tai's research experience included engineering education, e-learning, spatial ability and problem solving.

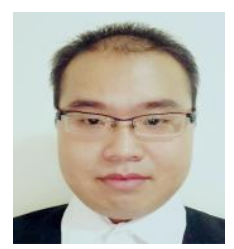

Ren-Cheng Zhang is Ph.D. candidate in the Department of Industrial Education and Technology, National Changhua University of Education. He majors in vocational education, and interested in applied statistics. He comes with a remarkably strong background in quantitative methods in education, with experience in hierarchical 1 inear modeling, meta-analysis, structural equation modeling and Experimental Analysis. Until now, his publications are especially in the field of applications of statistical methods, engineering education, and e-learning. 
Yu-Te Wang is Ph.D. candidate in the Department of Industrial Education and Technology, National Changhua University of Education. He was a senior high school teacher in Taiwan. He majors in vocational education, and interested in technology about Arduino and e-learning. He specializes in technology education, creative teaching and robot education.

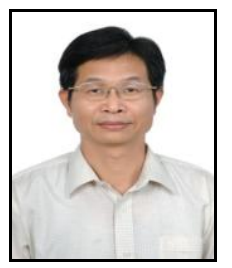

Ray Wang is associate Professor at the HungKuang University. He is a consultant for industry (Bureau of Employment and Vocational Training), and auditor for senior vocational high school (Ministry of Education). Professional service includes Quality Engineering (1987-96) and president consult (2004-05) of MyEnamel. He has received a M.S. and Ph.D. from the

University of Changhua of Education, both in College of Technology and Vocational Education. He is interested in human resource development and research into hospitality training programs. 